\title{
IZJAVE STRANAKA I PRIZNANJA ČINJENICA U POSTUPKU PROGLAŠENJA NIŠTAVOSTI ŽENIDBE
}

\author{
Marija Džinić - Zdenko Ilić
}

Sveučilište u Zagrebu

UDK: 27-452:347.624

Fakultet filozofije i religijskih znanosti marija.zivkovic@ymail.com

https://doi.org/10.34075/cs.54.4.4

Sveučilište Josipa Jurja Strossmayera u Osijeku

Pregledni znanstveni rad

Katolički bogoslovni fakultet u Đakovu

Rad zaprimljen 1/2019.

iliczde@gmail.com

\section{Sažetak}

U redovitom postupku proglašenja ništavosti ženidbe izjave i priznanja stranaka prvi su i temeljni dokaz utvrđivanja (ne)valjanosti sklopljene ženidbe. Aktualni Zakonik kanonskog prava u kann. 15301538 i kan. 1679 donosi odredbe o izjavama i priznanju stranaka te njihovoj valutaciji u svojstvu dokaznog materijala.

Kako bi se što preciznije ukazalo na važnost izjava stranaka, a koje su novu dimenziju poprimile m. p. Mitis Iudex Dominus Iesus, tema je obuhvaćena u širem kontekstu. U prvome dijelu članka tumači se iter ispitivanja stranaka, odnosno surha njihova ispitivanja; ovlasti i dužnosti suca preslušatelja; način ispitivanja; dužnosti stranaka s obzirom na sudjelovanje te obvezu odgovaranja uz predviđenu mogućnost odbijanja odgovora.

Drugi dio članka analizira sudsko i izvansudsko priznanje, dokaznu vrijednost izjava i priznanja te praksu Rimske rote s obzirom na problematiku. Zaključni dio posvećen je promjeni nastaloj reformom kanonskoga postupka proglašenja ništavosti ženidbe, proglašene $m$. p. Mitis Iudex Dominus Iesus, 2015. godine.

Ključne riječi: stranke, izjave, priznanja, dokazi, m. p. Mitis Iudex Dominus Iesus.

\section{UvoD}

U postupničkom pravu declarationes partium čine prvo poglavlje o dokazima, što ih svrstava u rang pravih i veoma bitnih dokaza. To prvenstvo nije samo sistematske nego i vrijednosne naravi, ukoliko je namjera zakonodavca bila rasporediti i klasificirati dokaze $\mathrm{s}$ 
obzirom na njihovu ulogu i vrijednost u dokazivanju istine, konačnoga cilja sudskog postupka. ${ }^{1}$

U širemu smislu, izjave stranaka podrazumijevaju apsolutno sve izjave prikupljene za vrijeme trajanja procesa, počevši od tužbe. Ovaj tip izjava nema izravnu dokaznu vrijednost iako uz ostali dokazni materijal mogu pomoći sucu u rješavanju spornoga pitanja. Prema tomu, one čine actis koje, tek uz pridodane probatis, čine temelj stjecanja moralne sigurnosti. U užemu smislu, pak, dokaznim materijalom smatraju se samo one izjave stranaka aktualizirane za vrijeme trajanja istražne faze sudskoga postupka, konkretno, preslušanjem stranaka.

Budući da su stranke neposredno pogođene osobe u postupku proglašenja ženidbe ništavom, u najvećem broju slučajeva, njihova izjava je najrelevantnija. U posebnoj mjeri to vrijedi za postupke $u$ kojima je temelj za proglašenjem ništavosti jedan od sljedeća tri: $o b$ simulationem, ob metum i ob condicionem. ${ }^{2}$

Kod utvrđivanja stupnja moralne sigurnosti o postojanju ili nepostojanju valjane ženidbene privole, izjavi stranaka mora se dati veliko značenje. Ipak, kod utvrđivanja istine, sudac je dužan ispitati u kojoj mjeri su stranke u svojim izjavama, slaganjima i pojašnjenjima doista objektivne i govore $u$ prilog istini. Ne čudi stoga što $u$ posljednje vrijeme sudska praksa sve veći interes daje upravo analizi izjava stranaka, protagonista sudskoga postupka.

U svrhu doprinosa istomu služi i ovaj članak koji nakon kratkog povijesnog prikaza sudske prakse $s$ obzirom na materiju, analizira uloga suca u istražnoj fazi postupka te daje prikaz (su)djelovanja stranaka u postupku. Potom dotiče način aktualizacije spomenutih iskaza, možebitnih iudicialis et extraiudicialis. Osvrće se na oba načina analizirajući njihov sadržaj i težinu u svjetlu confessiones ili priznanja te declarationes ili izjava. U tom kontekstu analizirani su kann. 1530-1538 aktualnog Zakonika uspoređujući ih s kann. 1742-1746 Zakonika kanonskog prava iz 1917. Neminovno je, također, prezentirati odredbe Instrukcije Dignitas connubii (dalje: DC), konkretno čll. 179-182 nastojeći utvrditi njihov utjecaj na praksu crkvenih sudova, napose Rimske rote, pri donošenju presuda o ništavosti ženidbe.

Usp. Communicationes, 2 (1970.) 185; 8 (1976.) 189.

2 Detaljnije usp. Raymond L. Burke, La confessio iudicialis e le dichiarazioni giudiziali delle parti, u: I mezzi di prova nelle cause matrimoniali secondo la giurisprudenza rotale, Studi giuridici XXXVIII, Città del Vaticano, 1995., 22-29. 


\section{OD ZAKONIKA 1917. DO ZAKONIKA 1983.}

Iako prethodni Zakonik izjavama stranaka nije davao izravnu dokaznu snagu, brojne rasprave među savjetnicima pokazuju kako su iste, u sudskoj praksi, itekako bile uvažavane. Naime, savjetnici za izradu Zakonika kanonskoga prava iz 1917. raspravljali su o vrednovanju izjava stranaka u kontekstu govora o slobodi suca u postupku proglašenja ništavosti ženidbe. Iako je većina izjave smatrala vrijednim dokazom, Schema 1 iz 1908., nastala na temelju votuma Fischera, Novala i Manya, negirala je dokaznu snagu izjave stranaka uzetih samostalno, odnosno bez dodatnih dokaza. Isto je ponovljeno i u Schemi 2 iz 1909: "Debent a iudice respui probationes factorum a partibus oblatae ... $3^{\circ}$. quae a parte pro suo lubitu confectae sunt extra iudicium, ceu praesertim sunt gratiosae suffragationes et ultroneae declarationes aut attestationes" (Schema 1 inc, can. 50). Naposljetku, posljednja Schema 10, ujedno uvrštena u Zakonik iz 1917, zadržala je isto stajalište. ${ }^{3}$

U finalnome tekstu Zakonika kanonskoga prava iz 1917. postupak ispitivanja stranaka bio je predviđen izvan naslova koji je obuhvaćao sudske dokaze. Tako je Naslov IX. De interrogationibus partibus in iudicio faciendis (cann. 1742-1746) prethodio Naslovu X. De probationibus (cann. 1747-1836). ${ }^{4}$ Izjave stranaka dokaznu snagu imale su samo u parnicama koje su se ticale privatnoga dobra. $\mathrm{Na}$ istome tragu kretala se i instrukcija Kongregacije za sakramente, Provida Mater Ecclesia, iz 1936. godine, zastupajući nedostatnost dokazne snage izjava supružnika. ${ }^{5}$ Princip koji je vodio ovakvu tezu temeljio se na pesimističkome shvaćanju osobe, koja je često sklona lagati u obrani vlastitih interesa. Tako je izjava stranaka smatrana dokazom bona fide jer se ne daje u vlastitu korist već je usmjerena protiv same stranke i u korist druge stranke u postupku. Neosporna je, dakle, činjenica kako je izjava stranaka ipak predstavljala svojevrsnu vrstu dokaza. Instrukcija na taj način nije isključila dokaznu relevantnost, nego samo njezin apsolutni i isključivi karakter. ${ }^{6}$

3 Usp. Joaquín Llobell, La genesi dei disposti normativi sul valore probatorio delle dichiarazione delle parti, Fidelium Iura, 12 (2002.), 141-148.

4 Detaljnije vidi: Slavko Zec, Mitis Iudex Dominus Iesus. Blagi sudac Gospodin Isus. Komentar i primjena, Zagreb, 2017., 97-98.

5 U članku 117. čitamo: "Depositio iudicialis coniugium non est apta ad probationem contra valorem matrimonii constituendam" (S. Congregatio Sacramentorum, Instructio servanda a tribunalibus dioecesanis in pertractandis causis de nullitate matrimoniorum Provida Mater Ecclesia, AAS 28 (1936.) 337 (dalje: PM).

6 Tako García Faílde komentirajući citirani članak 117 Instrukcije PM zaključuje kako "esto no quiere decir que la deposición judicial de los cónyuges no pueda 
Analizirajući prethodno zakonodavstvo, uočava se kako je kan. 1975, u slučajevima impotencije i nekonzumirane ženidbe, izjavama stranaka pridavao pomoćnu vrijednost, uvažavajući svjedoke koji će potvrditi vjerodostojnost danih izjava. Uz spomenute svjedoke te druge dokazne argumente izjave stranaka mogle su poslužiti sucu kao sredstvo postizanja moralne sigurnosti. ${ }^{7}$ Upravo će se na te iste svjedoke de credibilitate, gotovo stoljeće nakon stupanja na snagu Zakonika kanonskoga prava iz 1917., pozvati i m. p. Mitis Iudex Dominus Iesus reformirajući kanonski postupak proglašenja ništavosti ženidbe.

Za razliku od svojevrsne "rezerve" Zakonika kanonskog prava, crkveni sudovi valorizirali su izjave stranaka kao dokaza, a neki su ništavost proglasili isključivo na ovome temelju. Jedna od takvih je i poznata presuda coram Pinto od 14. travnja $1974 .^{8}$

Sve spomenuto, bilo kroz teoriju bilo kroz praksu sudova, utjecalo je na reformu. U prvome redu, postojala je volja da se novim Zakonikom prevlada nepovjerenje s obzirom na dokaznu snagu izja-

constituir prueba alguna contra la validez del matrimonio (como el término 'no est apta' pudiera dar a entender”. Juan José García Faílde, Tratado de derecho procesal canónico, Salamanca, 2007., 205.

7 Can. 1975 §1: "In causis impoteniae vel inconsummationis, nisi de impotentia vel inconsummatione alliunde certo constet, debet uterque coniux testes, qui septimae manus audiunt, inducere, sanguine aut affinitate sibi coniunctos, sin minus vicinos bonae famae, aut alioquin de re edoctos, qui iurare possint de ipsorum coniugum probitate, et praesertim de veracitate circa rem in controversiam deductam; quibus iudex ad normam can. $1759 \S 3$ alios testes potest ex officio adiungere. §2 Testimonium septimae manus est argumentum credibilitatis quod robur addit depositionibus coniugum; sed vim plenae probationis non obtinet, nisi aliis adminiculis aut argumentis fulciatur". Usp. Stefan Margelist, Die Beweiskraft der Parteiaussagen in Ehenichtigkeitsverfahren, Serie Diritto canonico 14, Roma, 1997., 124-125. O odnosu svjedoka pozvanih posvjedočiti vjerodostojnost samih stranaka te dokaznoj vrijednosti izjava usp. S. Congregatio Concili, Instructio pro confectione processus in causis matrimonialibus, 22. kolovoza 1840. §11, ASS 1 (1865.-1866.) Instrukcija pojašnjava kako se radi o sedam svjedoka predloženih od strane muža te sedam svjedoka predloženih od strane žene, a koji će posvjedočiti o karakteru stranaka u slučaju impotencije ili nekonzumirane ženidbe.

8 c. Pinto, 14. 4. 1974., u: Apostolicum Rotae Romanae Tribunal, Decisiones seu sententiae 1974., str. 272-281, br. 66. Parnicu je Rota riješila primjenom Regulae servandae a Vicariatu Apostolico Sueciae, a za konkretni slučaj ključan je sljedeći dio unutar njezina sadržaja: "Inspecto [...] uno naturae iure vera atque plena moralis certitudo de nullitate matrimonii haberi potest a sola partium aut earum alterutrius emissa declaratione, dummodo earum credibilitatis ac veracitas aestimari possit omni exceptione maior, talis nempe quae omne prudens contrarii dubium excludat; cui comparandae probe inservire posunt testes iurati ac fidedigni” (S.C.S. Officii, Regulae servandae a Vicariatu Apostolico Sueciae in pertractandis causis super nullitate matrimonii acatholicorum, 12 novembre 1947, 12 giugno 1951, Instructio n. 11, Documenta recentoria circa rem matrimonialem et processualem, II, Romae, 1977., n. 5436, 119. 
ve stranaka; nadalje, potreba definiranja razlike između parnica $u$ kojima je posrijedi privatno dobro od onih u kojima se radi o javnome dobru. Kao posljednje, nastojao se izbjeći formalizam u svrhu čega se je više puta naglasila slobodna razboritost suca pri vrednovanju izjave stranaka. ${ }^{9}$ Kao rezultat spomenutoga izjave stranaka u reformiranome Zakoniku, uključene su pod Naslov IV Dokazi, knjige VII Zakonika. Na ovaj pomak neosporno je u velikoj mjeri utjecala i praksa Rimske rote te svakako iskazivanje veće otvorenosti i povjerenja prema strankama i njihovim svjedocima. ${ }^{10}$

\section{IZJAVE STRANAKA U ZAKONIKU 1983.}

Norme koje treba uzeti u obzir analizirajući dokaznu snagu izjava stranaka sadržane su u kann. 1530-1538 općenito i u kan. 1679 u postupku proglašenja ništavosti ženidbe, a koji predviđa da sudac, za procjenu iskaza stranaka prema odredbi kan. 1536, upotrijebi, uz druge pokazatelje i pomagala, ako je moguće, svjedoke o vjerodostojnosti samih stranaka, osim ako odrugud ima potpune dokaze. ${ }^{11}$

\subsection{Ovlast i dužnosti suca (kan. 1530)}

Ispitivanje stranaka obvezatno je samo u parnicama koje se tiču javnoga dobra (ad probandum factum quod publice interest extra dubium poni). ${ }^{12} \mathrm{U}$ parnicama koje se tiču privatnoga dobra ispitivanje se vrši na zahtjev samoga suca (ex officio) ili na zahtjev jedne

9 Usp. Miguel Antonio Ortiz, La forza probatoria della dichiarazioni delle parti, u: H. Franceschi-M.A. Ortiz (ed.), Verità del consenso e capacità di donazione. Temi di diritto canonico matrimoniale e processuale, Roma, 2009., 394.

10 Usp. Pericle Felici, Juridical formalities end evaluations of evidence in the canonical process, The Jurist 38 (1978.), 153-157; Ian Gordon, De nimia processuum matrimonialium duratione. Factum-Causae-Remedia, Periodica, 58 (1969.), 687-688; Daniela Treglia, Le dichiarazioni delle parti nel processo canonico (I), Caietele Institutului Catolic , br. 1-2 (19-20) 2012., 204.

11 Članak 138 §1 Instrukcije PM formalno je propisivao da se o svim svjedocima traži svjedočanstvo o poštenju i vjerodostojnosti. Iako novi Zakonik ne spominje isto, nema sumnje da spomenuta odredba još uvijek vrijedi, ako ne za sve svjedoke, onda barem za one za koje sudac procijeni da je potrebno. Usp. Ian Gordon, Novus processus nullitatis matrimonii. Iter cum adnotationibus, Romae, 1983., 33; Nikola Škalabrin, Postupci, Đakovo, 2000., 255.

12 Pod "javnim dobrom" podrazumijeva se postupak proglašenja braka ništavim, postupak proglašenja ređenja ništavim, parnice rastave ženidbenih drugova, postupak izricanja kaznene mjere i drugi procesi, za koje biskup smatra kako prijete općem dobru (usp. kan. 1431). 
od stranaka ili čak branitelja veze ili promicatelja pravde, ukoliko sudjeluju u postupku. ${ }^{13}$

U parnicama o ništavosti ženidbe ispitivanje stranaka ne može se promatrati samo kao pravo ili mogućnost prepuštana sučevoj razboritosti. Naprotiv, radi se o obvezi kako izričito navodi i DC. Već sam poziv stranaka na saslušanje mora biti takav da ga stranka prihvati te tako, svojim iskazom, pridonese rješenju spora. ${ }^{14}$

Iako se ispitivanje može izvršiti u bilo kojem trenutku postupka, većina smatra kako je to onaj između contestatio litis i conclusio in causa (uvažavajući kann. 1529 i 1600). ${ }^{15}$ Opća praksa predviđa ispitivanje stranaka na samome početku dokazne faze postupka.

\subsection{Način ispitivanja stranaka}

Ukoliko je svrha ispitivanja priznanje činjenica, način ispitivanja mora biti prilagođen upravo tom cilju. Iz propisa kann. 15321534 moguce je izdvojiti indikacije koje je potrebno primijeniti kod ispitivanja stranaka i koje, u konačnici, jamče zakonitost ispitivanja. ${ }^{16}$ Navedenim kanonima pridodaju se i oni koji se odnose na ispitivanje svjedoka, a koji, u određenoj mjeri, vrijede i pri ispitivanju stranaka. U pravilu se stranke trebaju saslušati u sjedištu suda, ukoliko se sucu ne čini da bi bilo poželjno nešto drugo ili se radi o kardinalima, patrijarsima, biskupima ili osobama koje prema državnom zakonu priželjkuju sličnu naklonost (usp. kan. 1558).

Saslušanje provodi sudac, njegov opunomoćenik ili sudac istražitelj (usp. kan. 1561). Ukoliko su kod saslušanja nazočni odvjetnici, crkveni odvjetnik ili branitelj veze, a žele postaviti neka pitanja, postavljaju ih onome koji vodi saslušanje te ih tek on izravno postavlja stranci ili strankama. Budući da pri ispitivanju druga stranka ne

13 Usp. Paolo Bianchi, Alcune annotazioni circa l'interrogatorio di parti e testi nelle cause di nullità di matrimonio, Quaderni di diritto ecclesiale, 17 (2004.), 210.

14 Tako komentar na prvo poglavlje Naslova IV, Dokazi, unutar Código de Derecho Canónico navodi kako stranke na zakonit upit suca mogu "corregir las impreciones o erores de los escritos de demanda y de contestación; enriquecer con sus relatos la verdad histórica de los hechos, con cirunsctancias e indicios que pongan aj juez en camino de conocer sólo y toda la verdad. Obtenido el esclarecimiento de los hechos e de sus circunstancias, es fácil ver que medios instructorios hacen falta para acreditar los hechos controvertidos, y qué pruebas serán oportunas y relevantas". Código de Derecho Canónico, Sexta edición revisada y actualizada, Pamplona, 2001., 950.

15 Tako npr. Michael Paul Hilbert, Le dichiarazioni delle parti nel processo matrimoniale, Periodica 84 (1995.), 739-741; Francis G. Morrisey, L'interrogation des parties dans les causes de nullité de mariage, Dilexit iustitiam, 366.

16 Vidi također i DC 162-176. 
smije biti nazočna, ona ima pravo podastrijeti odgovarajuća pitanja sucu samo izvan ovog saslušanja. ${ }^{17}$

Kod saslušanja je nužna prisutnost bilježnika. Nakon očitovanja o identitetu sudac mora pitati stranke o vezi s drugom strankom te istražiti odakle i kada je stranka došla do saznanja onoga o čemu daje iskaz (kan. 1563). ${ }^{18}$

Sudac mora podsjetiti stranke na njihovu obvezu govorenja istine (kan. 1562 §2; usp. $1531 \S 1$ ), ${ }^{19}$ te u slučajevima općega dobra zahtijevati prisegu, ukoliko to ne priječi nekakav težak razlog (kan. 1532; usp. kan 1562 §2).

\subsection{Dužnost upitane stranke (kan. 1531)}

Načelo kan. 1531, §1 ukazuje kako je na zakonit upit stranka obvezna odgovoriti i u cijelosti iznijeti istinu, dok je, kod kaznenih postupaka od iste obveze oslobođena optužena stranka (usp. kan. 1728 §2). ${ }^{20}$ Bitno je naglasiti kako je u Zakoniku kanonskoga prava iz 1917. obveza odgovora bila pod kaznenom odgovornošću, dok se isto formalno ne propisuje $\mathrm{u}$ aktualnome Zakoniku. Navedeno, ipak, ne isključuje mogućnost primjene određenoga partikularnog kaznenog zakona ili zapovijedi u slučaju nepoštivanja zakonske obveze odgovora.

Prema kan. 1564, koji se, istina, odnosi na ispitivanje svjedoka, mogu se istaknuti elementi koji čine nezakonit upit stranke. Nezakonit upit bio bi takav ili zbog svoga sadržaja ili zbog načina samoga upita, kao što je npr. ispitivanje bez prethodnoga poziva same stranke; bez prisutnosti bilježnika; izvan sjedišta samoga suda, a bez opravdana razloga; ispitivanje koje nema nikakve veze s objektom same parnice; ispitivanje o materiji koja dotiče sakrament ispovijedi i dr. Isto tako, pitanje koje bi išlo u cilju transformiranja tužene stranke u stranku tužiteljicu, ne bi se smatralo zakonitim niti bi iziskivalo obvezu odgovora. ${ }^{21}$

17 Usp. Nikola Škalabrin, Postupci, Đakovo, 2000., 254-255.

18 Usp. Ian Gordon, Novus processus nullitatis matrimonii. Iter cum adnotationibus, Romae, 1983., 29; Nikola Škalabrin, Postupci, Đakovo, 2000., 170-171.

19 Usp. Paolo Bianchi, Alcune annotazioni circa l'interrogatorio di parti e testi nelle cause di nullità di matrimonio, Quaderni di diritto ecclesiale, 17 (2004.), 213.

20 U svome članku prof. Hilbert podvlači upravo termin respondere razlikujući ga od collaborare. Razlog tomu vidi u činjenici što je prvi termin puno jasniji, a isto tako, suradnja (collaborazione) se ne može nikome propisati. Stoga je obveza odgovoriti na zakonit upit suca zakonska obveza, dok je obveza suradnje moralna obveza. Usp. Michael Paul Hilbert, Le dichiarazioni delle parti nel processo matrimoniale, Periodica, 84 (1995.), 742., nota 14.

21 Usp. Paolo Montini, Il processo di nullità matrimoniale, Rivista di scienze religiose, 21 (2007.), 70. 
Obveza odgovora na zakonit upit jasna je i logična. Ukoliko stranka traži posredovanje suda, time i sama preuzima obvezu osobne suradnje i zalaganja za što bržim rješenjem spora. Navedeno, očigledno, u prvome redu vrijedi za tužitelja, dok je obveza tužene stranke, u ovome kontekstu, ponajprije vezana uz zakonito priznatu vlast suca.

\subsection{Vrednovanje šutnje}

Kan. 1531 §2 navodi: “Ali, ako odbije odgovarati, sučeva je zadaća da prosudi što se iz toga može zaključiti da bi se dokazale činjenice." Vrednovanje šutnje kroz povijest je različito tumačeno. ${ }^{22}$ Dekretali su odbijanje odgovora tumačili kao priznanje. Točnije, za tužitelja je predstavljalo završetak njegova djelovanja, a za tuženu stranku je značilo priznanje. Zakonik kanonskoga prava iz 1917. ipak je prepuštao sucu vrednovanje ovoga slučaja, uz napomenu kan. 1743 §2, u kojemu se predviđala mogućnost vrednovanja šutnje stranke kao izjave protiv same sebe, odnosno pro validitate vinculi. ${ }^{23}$

Ukoliko stranka ne želi dati izjavu, sudac je ne može na to prisiljavati već samo poduzeti sve potrebne korake kako bi potaknuo na suradnju. Slobodnoj prosudbi suca o odbacivanju davanja izjave kan. $1531 \S 2$ ne stavlja ograničenja, ali nužno se moraju pojasniti okolnosti koje su dovele do njezina uskraćivanja. ${ }^{24}$

Vrednovati šutnju nije lako, jednako kao ni procijeniti što bi ona značila s obzirom na činjenice koje su prethodile tužbi. U ovome slučaju autori se pozivaju na poznatu regulu iuris: Expressa nocent, non expressa non nocent. Šutnja se ne može iskoristiti protiv stranke koja je odbila odgovoriti, ne može se koristiti kao priznanje. Njezino vrednovanje potrebno je staviti u jedan puno širi kontekst, a to bi značilo vrednovati cjelokupno stanje osobe (je li stranka u strahu, ljuta, zbunjena, sramežljiva kada se govori o stvarima koje ulaze u intimu; način na koji doživljava sam crkveni sud i dr.). Isto tako, treba nastojati utvrditi odbija li stranka odgovoriti zato što bi svojom izjavom samo pogoršala situaciju u kojoj se nalazi ili iz nekih sasvim oprečnih razloga.

22 Neki od primjera: "Qui tacet consentire videtur" (C. 43, v, de regulis iuris, 12 , $\mathrm{VI}^{\circ}$ ); "Is qui tacet non fatetur, sed nec utique negare videtur" (C. 44, V, de regulis iuris, $12, \mathrm{VI}^{\circ}$ ). Jedna od najpoznatijih je svakako sljedeća: "Expressa nocent, non expressa non nocent” (Mod. 1, 195 D. de regulis iuris 50, 17).

23 Can. 1743\$2: "Si pars legitimeinterrogata respondere recuset, quantifacienda sithaec recusatio, utrum iusta sit, an confessioni aequiparanda, necne, iudicis est aestimare".

24 Usp. Paolo Montini, Il processo di nullità matrimoniale, Rivista di scienze religiose, 21 (2007.) 70. 
Zaključno, za jedne šutnja predstavlja indiciju koja se vrednuje s obzirom na svaku pojedinu situaciju i u svom vlastitom kontekstu $^{25}$ dok za druge nema nikakvo posebno značenje. ${ }^{26}$

\section{SUDSKO PRIZNANJE}

Prema kan. 1535 “Tvrdnja o nekoj činjenici, pisana ili usmena, koju neka stranka pred mjerodavnim sucem iznese u samom predmetu suđenja protiv sebe, bilo svojevoljno bilo na upit suca, sudsko je priznanje”. Sudsko priznanje sastoji se od 6 elemenata: tvrdnja o nekoj činjenici; mjerodavni sudac; stranka u postupku; sâm predmet suđenja; svojevoljno ili na upit suca; protiv sebe. Upravo su ovo temeljni elementi sudskog priznanju u užem smislu budući se radi o nekoj tvrdnji koju stranka iznosi pred sucem, i to protiv sebe.

Aktivni subjekt sudskog priznanja jedna je od stranaka koja to priznanje može učiniti bilo svojevoljno bilo na upit mjerodavnog suca. Pasivni subjekt je sâm mjerodavni sudac pred kojim se odvija sudsko priznanje, dok je objekt sudskog priznanja neka činjenica vezana uz sam predmet suđenja. Način na koji se sudsko priznanje može odvijati je dvostruk: bilo pisanim putem bilo usmeno. ${ }^{27}$

Daljnja karakteristika sudskog priznanja jest da je ono usmjereno contra se, tako da uzrokuje ili može uzrokovati štetu bilo samoj stranci bilo ženidbenom vezu. U kontekstu rečenoga postoje tri poimanja sudskog priznanja u parnicama ništavosti ženidbe:

a) Priznanje protiv valjanosti ženidbe ili protiv vlastita životnog staleža

25 "No es tarea fácil estimar jurídicamente el silencio, en cuanto manifestación reveladora de hechos históricos pasados. Si fuera equivalente a una admisión tácita del hecho, tendríamos una confesión; pero a esto se opone una regola de derecho: expressa nocent, non expressa non nocent. Creemos que sólo puede darse al silencio la fuerza de un indicio, cuyo sentido puede ser diverso según los casos y las circunstancias". Código de Derecho Canónico, Sexta edición revisada y actualizada, Pamplona, 2001., 950. Termin indicium probationis ponavlja se i u Commentario exegetico al Código de Derecho Canónico: "Parece que, como mucho, la negativa de la parte a responder puede considerarse un indicio (indicium probationis), que puede significar diversas cosas, según el caso y las circunstancias". can. 1531, u: Commentario exegetico al Código de Derecho Canónico, V/2, 1292.

26 Kako stoji u komentaru Lüdickea: "Die Weigerung der Gegenpartei in Personenstandssachen ist ohne Beweisbedeutung". Klaus Lüdicke, Münstericher Kommentar zum Codex Iuris Canonici, Essen, 1999., kan. 1531, 2.

27 Usp. Giordano Caberletti, Le dichiarazioni delle parti (artt. 177-182), u: Il giudizio di nullità matrimoniale dopo l'Istruzione "Dignitas connubii", Parte terza, La parte dinamica del processo, Città del Vaticano, 2008., 349. 
b) Priznanje protiv vlastite teze u postupku

c) Priznanje da je stranka sama uzrokovala ništavost vlastite ženidbe.

Usporedbom kan. 1535 važećeg Zakonika ${ }^{28}$ te kan. 1750 Zakonika kanonskog prava iz $1917 .{ }^{29}$ uočavaju se određene razlike. Dok $\mathrm{u}$ važećem Zakoniku stoji jedino izraz contra se, u prijašnjem Zakoniku postojao je još jedan element: contra se et pro adversario. Dok je službeni prijevod contra se sadržan u kan. 1535, "protiv sebe", doimlje se čudnim prijevod istog izraza kojeg nalazimo u kan. 1750. On je preveden riječima "bilo od svoje volje". Bez obzira na razlike u prijevodu, postavlja se pitanje zašto je pri reformi Zakonika kanonskoga prava iz 1917. ispušten izraz et pro adversario ("u korist protivnika”, a odgovor pruža detaljnija interpretacija izraza contra se.

Naime, kada se u sudskom priznanju iznosi neka tvrdnja "protiv sebe", ona je usmjerena "u korist protivnika". Osim ovoga tautološkog razloga postoji i drugi. Dekretali koriste isključivo izraz contra se, te je, prema tome, aktualni kanon vjerniji kanonskoj tradiciji redovitog parničnog suđenja.

Nadalje, razliku između dva navedena kanona čini i tehnička jasnoća ukoliko izrazu coram iudice, Zakonika kanonskoga prava iz 1917., kan. 1535 aktualnog Zakonika dodaje izraz competenti te dodatak circam ipsam iudicii materiam.

Na temelju sličnosti i razlika sudsko priznanje moguće je promatrati na dvije razine. S obzirom na način odvijanja ono može biti svojevoljno ili slobodno te na upit suca, odnosno nametnuto. Ukoliko su sudsko priznanje ili neka druga izjava iznuđeni prisilno ili zbog velikog straha, tada su oni nevaljani (usp. kan. 1538). Dakle, pri saslušanju stranaka sudac koji saslušava treba biti vrlo oprezan te ostati u granicama dopuštenog. S obzirom na eventualna ograničenja i načine izvođenja sudsko priznanje može biti Confessio simplex, ukoliko iznosi same činjenice bez njihova modificiranja, i Confessio complex, ukoliko uz činjenice iznosi i dodatne elemente kojima se mijenja sâmo shvaćanje tih činjenica mijenjajući im kontekst.

Bitna značajka sudskog priznanja temelji se na izričitoj premisi prema kojoj nitko nije dužan djelovati protiv sebe (nemo contra se agere censetur) te je stoga lakše lagati u vlastitu korist nego govori-

28 Can. 1535: "Assertio de aliquo facto, scripto vel ore, coram iudice competenti, ab aliqua parte circam ipsam iudicii materiam, sive sponte sive iudice interrogante, contra se peracta, est confessio iudicialis."

29 Can. 1750: "Assertio de aliquo facto, in scriptis aut oretenus ab una parte contra se et pro adversario coram iudice, sive sponte, sive iudice interrogante peracta, dicitur confessio iudicialis." 
ti protiv sebe (facile est mentiri pro se, difficillium mentiri contra se). Upravo zbog te bitne značajke sudskog priznanja djelovanje contra se u kontekstu izjavâ stranaka u parnici podrazumijeva da one ne djeluju nužno protiv sebe, nego protiv ženidbenog veza. Jednako tumačenje nudi i instrukcija DC $179 \S 2 .^{30}$

\section{DOKAZNA VRIJEDNOST IZJAVA I PRIZNANJA}

Jedno od temeljnih pitanja postupka ništavosti ženidbe jest vrednovanje izjave stranaka, bilo da se radi o sudskom ili izvansudskom priznanju. Naime, Instrukcija PM, zbog nedostatka pravne jasnoće o vrednovanju izjava stranaka u Zakoniku kanonskoga prava iz 1917., u čl. 117 propisivala je sljedeće: "Depositio iudicialis coniugum non est apta ad probationem contra valorem matrimonii constituendam." $\mathrm{Na}$ ovu vrlo krutu odredbu ozbiljnije je reagirao tek 1977. godine kard. Pericle Felici, koji se pitao može li iskaz stranke u postupku biti lišen svake pravne težine iako se ona dobro sjeća činjenica te slobodno i odgovorno, pod prisegom, odgovara na questiones suca istražitelja. ${ }^{31}$

Ozbiljnije se ovom problematikom bavio i Ignacio Gordon te bi se, prema njegovu mišljenju, sudsko priznanje stranaka moglo vrednovati kao potpuni dokaz pod dva uvjeta. Prvi bi se odnosio na nedostatak ostalih dokaza jer, ako ih ima, objektivnost dokaza u parnicama koje se tiču općeg dobra nužno bi zahtijevale procjenu i valorizaciju. Drugi uvjet bi bio da se strankama prizna vjerodostojnost, i to na temelju vjerodostojnih svjedoka. ${ }^{32}$

Djelomično jasan odgovor na ovu problematiku donio je, prije svega, aktualni Zakonik kanonskoga prava u kann. 1536 § 2 i 1679. Međutim, tek su nedavnom reformom kanonskog postupka, prema m. p. Mitis Iudex Dominus Iesus, izjave stranaka revalorizirane te je kan. 1679 poprimio novi smisao. Kako bismo na što jasniji način prenijeli i prikazali novi pristup valoriziranju izjave stranaka, te zašto je do njega došlo, potrebno je ukratko prikazati praksu koja mu je prethodila. Konkretno, usporediti kann. 1536 § 2 i 1679, sada reformirani kan. 1678, a čime se nastoje utvrditi manjkavosti njihova sadržaja te praktične primjene.

30 DC 179 §2: "Attamen in causis nullitatis matrimonii confessio iudicialis intellegitur declaratio qua pars, scripto vel ore, coram iudice competenti, sive sponte sive iudice interrogante, asserit proprium factum adversus matrimonii validitatem."

31 Usp. Raymond L. Burke, La confessio iudicialis e le dichiarazioni giudiziali delle parti, 15-16.

32 Ignacio Gordon, De nimia processuum matrimonialium duratione: factum, causae, remedia, Periodica, 58 (1969.), 692. 
4.1. Odnos između izjava i priznanja prije reforme kanonskog postupka

Spomenuti kann. 1536 § 2 i 1679, a koji će s m. p. Mitis Iudex Dominus Iesus poprimiti novi sadržaj, jedna su od najvećih novina Zakonika kanonskoga prava iz 1983., koji su ipak stvarali nemale poteškoće u konkretnoj primjeni. S jedne strane, uočava se neprestana sumnja $u$ iskrenost stranaka i njihovih priznanja i izjava. $\mathrm{S}$ druge, pak, strane sve češće se pojavljuje praksa automatskog prihvaćanja izjava stranaka kao apsolutnog i isključivog dokaza. ${ }^{33}$

U cilju nadvladavanja navedenih poteškoća Zakonodavac je upravo tim kanonima naglasio tri važna elementa koji su nit vodilja vrednovanja iskaza stranaka u postupku. Kao prvo, nadilaženje nepovjerenja prema strankama i njihovim tvrdnjama pro nullitate matrimonii. Kao drugo, potreba različita pristupa vrednovanju sudskog priznanja stranaka u parnicama o nekom privatnom poslu od onih koje se tiču javnog dobra, napose o ništavosti ženidbe. Kao treće, posljednje, volja izbjeći svaki formalizam od strane suca koji ima potpunu slobodu vrednovanja izjava stranaka zajedno s drugim elementima prisutnim u parnici.

Složeni odnos između kann. $1536^{34}$ i 1679 nije lako primijeniti u konkretnom slučaju. Naime, prvi kanon donosi opće odredbe redovitog parničnog suđenja u slučajevima javnog dobra, dok se drugi konkretno odnosi na ništavost ženidbe. Budući da kan. 1679 izričito upućuje na kan. 1536 (kan. 1536, pak, ne upućuje na kan. 1679; sic!), zajedno ćemo ih promatrati, i to u suodnosu specifičnost-izjave.

Sadržaj ova dva kanona po sebi je prilično jasan: izjave stranaka na sudu koje nisu priznanja mogu imati - i u parnicama koje se tiču javnog dobra, napose ženidbenim - određenu vrijednost dokaza koje sâm sudac slobodno vrednuje prema vlastitoj savjesti. Međutim, one mogu imati i potpunu dokaznu snagu samo ako su prisutni drugi elementi koji posve potkrepljuju njihove izjave. A ti drugi

33 Usp. Miguel Antonio Ortiz, La forza probatoria delle dichiarazioni delle parti nelle cause di nullità del matrimonio, u: H. Franceschi - M.A. Ortiz, Verità del consenso e capacità di donazione. Temi di diritto canonico matrimoniale e processuale, Roma, 2009, 394.

34 Can. 1536 § 1: "Confessio iudicialis unius partis, si agatur de negotio aliquo privato et in causa non sit bonum publicum, ceteras relevat ab onere probandi. § 2 . In causis autem quae respiciunt bonum publicum, confessio iudicialis et partium declarationes, quae non sint confessiones, vim probandi habere possunt, a iudice aestimandam una cum ceteris causae adiunctis, at vis plenae probationis ipsis tribui nequit, nisi alia accedant elementa quae eas omnino corroborent." 
elementi su napose pokazatelji i pomagala te, ako je moguće, svjedočanstva o vjerodostojnosti samih stranaka.

Tri su specifičnosti kan. 1679 nad kojima se želimo zaustaviti:

1. “osim ako odrugud ima potpune dokaze [ništavosti ženidbe]”. U ženidbenim parnicama sudac se neće moći koristiti odredbama kan. 1536 § 2 ukoliko smatra da će steći moralnu sigurnost ništavosti ženidbe preko nekih drugih dokaza, a koji nisu izjave stranaka. Prema tome, odredba koju donosi kan. 1536 § 2 u supsidijarnom je odnosu s kan. 1679.

2. “za procjenu iskaza stranaka”. Kan. $1536 \S 2$ odnosi se na sudsko priznanje i izjave stranaka koje nisu priznanja. I jedno i drugo ne uključuje izvansudsko priznanje ni izvansudske izjave sadržane u kan. 1537. Kan. 1679 koristi izraz "iskazi stranaka [partium depositiones]" koje nisu izvansudska priznanja niti druge izvansudske izjave. Stoga, ograničen je cjelokupni govor o procjeni iskaza stranaka u postupku ništavosti ženidbe budući da se izričito ne odnosi na sudska priznanja ili druge sudske izjave stranaka koje nisu confessio iudicialis.

3. "upotrijebi, uz druge pokazatelje i pomagala, ako je moguće, svjedoke o vjerodostojnosti samih stranaka”. Ovim riječima kan. 1679 tumači i pojašnjava kratku odredbu kan. 1536 § 2: "osim ako se pridruže drugi elementi koji ih posve potkrepljuju".

Prema kan. 1536 § 2, pak, moguće je izdvojiti tri temeljne tvrdnje koje se odnose na izjave:

1. "izjave stranaka [...] mogu imati dokaznu snagu koju sudac treba da prosudi zajedno s ostalim okolnostima parnice". Naglasak ove odredbe je na glagolu "mogu". Prema tome, izjave stranaka possunt, non habere debent dokaznu snagu. Razlog te mogućnosti (possunt) nalazimo ponajprije u slučajevima kada izjave stranaka nemaju nikakvu težinu ukoliko se utvrdi da su dane "zbog zablude o činjenici ili da je dobivena prisilom ili zbog velikog straha” (kan. 1538). Drugim riječima, izjava stranke može biti iskrena, ali ne odgovarati istini budući da stranka krivo promatra i krivo tumači neku činjenicu. Nadalje, prema kanonskom uređenju, sudac je načelno slobodan u prosudbi dokaza proizašlih iz istražnog dijela postupka: "Dokaze pak sudac mora prosuđivati po svojoj savjesti, uz obdržavanje propisa zakona o djelotvornosti nekih dokaza” (kan. 1608 § 3). S jedne strane, zakon dodjeljuje određenu vrijednost dokazu kao takvom. S druge strane, sucu je ostavljena diskrecija u vrednovanju dokaza proizaš$\log$ iz iskaza stranaka u postupku. U tom vrednovanju dokaza 
na umu treba imati i ostale okolnosti parnice koje eventualno mogu utjecati na sučevu prosudba ništavosti ženidbe.

2. Izjavama stranaka se "ne može dati potpuna dokazna snaga”. Ovo je jedna od rijetkih pravnih odredbi s obzirom na djelotvornost dokaza. Ima negativan karakter ukoliko izričito potvrđuje da sudac u postupku izjavama stranaka nikada ne može dati snagu potpunog dokaza, čak niti "ex sua conscientia” (kan. 1608 § 3). Ona u toj mjeri obvezuje suca da bi u slučaju proglašenja ništavosti ženidbe na temelju izjava stranaka ta ista presuda bila ništava.

3. Izjave stranaka, "ako im se pridruže drugi elementi” mogu imati potpunu dokaznu snagu. Pitanje koje se očito postavlja jest koja su to alia elementa koja omogućuju da izjave stranaka imaju snagu potpunog dokaza.

\subsection{Alia elementa}

Sigurno je da se pod terminom alia elementa ne mogu naći pravi dokazi shvaćeni u užem smislu riječi. Ako bi tako bilo, tada bi kan. 1536 § 2 bio nerazumljiv. Naime, koja bi svrha bila nadodati druge dokaze samim izjavama stranaka kako bi one, ipak, imale snagu potpunog dokaza. Nadalje, sigurno je da alia elementa moraju potkrijepiti izjave stranaka. Ona su ipak, po svojoj biti, dokazno sredstvo koje služi izjavama stranaka. Upravo kan. 1679 daje konkretni primjer tih alia elementa, a to su svjedoci o vjerodostojnosti samih stranaka.

Činjenica je da vjerodostojni svjedoci nisu dovoljni da pridonesu potpunoj dokaznoj snazi izjavama stranaka. Nejasno je i diskutabilno odnose li se alia elementa na izjave stranaka ili na vrijednost tih izjava, odnosno na sam postupak. Čini se da odgovor opet nudi kan. 1679, koji određuje da sudac pri procjeni iskaza stranaka upotrijebi i alia indicia et adminicula, odnosno druge pokazatelje i pomagala.

\subsection{Alia indicia et adminicula}

Poteškoću stvara i razumijevanja drugih indicia et adminicula. Zbog različitosti mišljenja i tumačenja ovih pojmova poželjno ih je sažeti u dvije skupine. ${ }^{35}$

Prva skupina ih tumači kao dokaze koji se trebaju pridodati izjavama stranaka. Kao primjer navodimo tumačenje talijan-

35 Usp. Mario Francesco Pompedda, Il valore probativo delle dichiarazioni delle parti nella nuova giurisprudenza della Rota Romana, Ius Ecclesiae, 5 (1993.), 461-462; 466-467. 
skog kanonista C. Tricerrija prema kojemu su indicia ili pokazatelji sigurne činjenice koje logično upućuju na druge sigurne činjenice i stvarnosti. Pomagala ili adminicula su činjenične okolnosti koje potkrepljuju valjanost dokaza. ${ }^{36}$

Druga skupina smatra da indicia et adminicula nisu dokazi. Na toj je liniji i M. F. Pompedda, koji smatra da su jedino izjave stranaka pravi dokaz bez obveze za ostalim dokazima, koji su isključivo u službi vjerodostojnosti. ${ }^{37}$

Prema sigurnijem tumačenju, indicia ili pokazatelji su sigurne činjenice koje su izravno povezane s onim što su stranke izjavile te su kao takve prihvatljive (npr. obiteljski ili socijalni ambijent stranke ili njezina osobna povijest). Adminicula ili pomagala su ostale okolnosti, koje samo daju dodatnu vrijednost izrečenom.

Drugim riječima, ne radi se o elementima koji bi sami po sebi mogli biti potpuni dokazi jer bi u tom slučaju bila beskorisna kanonska odredba. Radi se o okolnostima koje se ne mogu uzeti kao dokazi u pravom smislu, nego, po svojoj naravi, potvrđuju vjerojatnost onoga što su stranke izjavile te time utječu na stvaranje potpunog dokaza. Upotreba pokazatelja i pomagala ima svoju pravnu korist onda kada je nemoguće doći do potpune dokazne snage izrečenog na suđenju, čak i uz pomoć vjerodostojnosti stranaka.

\subsection{Confessio et declaratio}

Na temelju kan. $1536 \S 2$ izjave parničnih stranaka mogu biti dvostruke: confessio ili priznanje te declarationes ili izjave. I jedna i druga, pak, mogu se očitovati bilo u sudskom bilo u izvansudskom priznanju. Ono što je bitno zamijetiti jest da je confessio u strogom smislu riječi priznanje protiv valjanosti ženidbe, dok declarationes to

36 Carlo Tricerri, commento al c. 1679, u: Commento al Codice di diritto canonico, Roma, 1985., 959: "Per la determinazione [...] del significato delle parole 'indizi' e 'amminicoli', possiamo ritenere che indizi siano le risultanze certe di fatti che servono a far dedurre logicamente l'esistenza di altre risultanze o fatti certi; mentre gli amminicoli di prova sono da intendersi come le circostanze di fatto, ad esempio la religiosità di una persona, il suo comportamento ecc. che servono a corroborare la validità di una prova."

37 Mario Francesco Pompedda, Il valore probativo delle dichiarazioni delle parti nella nuova giurisprudenza della Rota Romana, Ius Ecclesiae 5 (1993.), 463: “Quindi, anche qui [oltre che nel can. 1573 sul teste unico] la legge [can. 1679] - completando quasi e specificando quanto è detto in genere nel canone 1536 par. 2 - ammette che si possa avere piena prova unicamente sulle dichiarazioni delle parti, senza dover ricorrere ad altre prove ma semplicemente dimostrando che le medesime meritano piena credibilità." 
nisu. Naime, u ovom drugom slučaju radi se o bilo kojoj declaratio ili izjavi stranaka koje po sebi mogu pozitivno ili negativno utjecati na stjecanje moralne sigurnosti suca. Npr. to mogu biti prihvaćene izjave pri samom sudskom saslušanju ili izjave koje su stranke spontano izrekle prisjećajući se određenih elemenata do tada nespomenutih.

S obzirom na dokaznu vrijednost izjava stranaka možemo ih podijeliti u dvije skupine:

a) na temelju sadržaja, one mogu biti priznanja i ostale izjave. Priznanja ili confessiones podrazumijevaju ili neke činjenice protivne vlastitim interesima (kan. 1535, DC 179, § 1) ili tvrdnje neke vlastite činjenice protiv valjanosti ženidbe (čl. 179, § 2).

b) na temelju oblika, mogu biti sudske i izvansudske izjave. Sudske izjave ili declarationes iudicialis prikupljaju se tijekom istražne faze suđenja (DC 177-178), dok se declarationes extraiudicialis prikupljaju prije samog postupka te se uvode na suđenje po svjedocima koji su ih čuli ili po dokumentima u kojima se one nalaze.

Declarationes iudicialis prihvaćene su od samih stranaka $\mathrm{u}$ istražnoj fazi postupka, bez obzira na njihov sadržaj. Objekt su slobodnog vrednovanja od strane suca, zajedno s ostalim okolnostima parnice (DC 180, § 1). Sve sudske izjave, bile one priznanja ili ne, mogu steći potpunu dokaznu snagu dostatnu za postizanje moralne sigurnosti nad objektom parnice ako im se dodaju drugi elementi koji ih posve potkrepljuju (DC 180, §1).

Pouzdanost izjava stranaka treba vrednovati na temelju:

a) vjerodostojnosti same osobe: iskrenost i konkretna sposobnost reći istinu ili objektivna pouzdanost $u$ njihove izjave

b) objektivna istinitost sadržaja njihovih izjava koja proizlazi iz nutarnje dosljednosti tvrdnji jedne strane te izvanjske dosljednosti tvrdnji učinjenih od druge strane i svjedoka.

Declarationes extraiudicialis nisu učinjene osobno od strane stranaka, nego su uvedene na suđenje preko ostalih dokaznih instrumenata kao što su svjedočanstva i dokumenti. U ovome slučaju sucu se ostavlja sloboda u njihovu vrednovanju i prihvaćanju na suđenju.

\section{IZVANSUDSKO PRIZNANJE}

Važeći Zakonik ne donosi definiciju izvansudskog priznanja, nego određuje da je "sučeva zadaća da prosudi, pošto procijeni sve okolnosti, koliko vrijedi izvansudsko priznanje izneseno na suđe- 
nju" (kan. 153738). Definiciju izvansudskog priznanja donosi kan. 1753 Zakonika kanonskoga prava iz 1917: "Priznanje učinjeno bilo pismeno, bilo usmeno samomu protivniku ili drugim osobama izvan suda, zove se vansudsko: a na suca spada, ako se predloži sudu, ocijeniti, uzimajući u obzir sve stvarne prilike, koliko ono vrijedi." ${ }^{39}$

Prema tome, izvansudsko priznanje je priznanje bilo tužene stranke bilo drugih osoba izvan suda. Sudac će prihvatiti takvo priznanje ukoliko je zakonito učinjeno, i to na sljedeće načine: pomoću izjava druge stranke ili pomoću svjedočanstva svjedoka.

Od velikog su značenja izvansudska priznanja koja se odnose na vremensko razdoblje prije samog sklapanja ženidbe ili kratko razdoblje nakon sklopljene ženidbe, a kada se još nije sumnjalo u pokretanje navedenog postupka (tempus non suspectum). ${ }^{40}$

Osim toga, dokazna vrijednost ovakvih priznanja ovisi i o vjerodostojnosti samih svjedoka koji ih iznose na suđenju ili o nekom dokumentu dostavljenom sudu, a sudac će prosuditi njihovu vrijednost. U kanonskoj nauci izvansudsko priznanje uzima se s velikom suzdržanošću budući ono može biti učinjeno površno, općenito ili čak neistinito. Stoga su izvansudska priznanja dokazi koje treba dokazati ili probationes probandae.

\section{SUDSKA PRAKSA RIMSKE ROTE}

Iz letimičnog pogleda na presude ženidbenih parnica Rimske rote razvidno je da se odredbe o vrednovanju sudskih priznanja i izjava stranaka primjenjuju na različite razloge ništavosti ženidbe, a napose ukoliko se radi o ženidbama sklopljenim pod uvjetom, zbog himbe te velikog straha.

Confessio iudicialis sudska je praksa Rimske rote uvijek promatrala kao initium probationis, prihvaćen samo ako je utvrđena vjerodostojnost stranaka, ako su svjedoci vjerodostojni s obzirom na njihove iskaze te ako su potkrijepili ili potvrdili ono što su stranke izjavile $\mathrm{u}$ postupku. ${ }^{41}$

38 Can. 1537: "Quoad extraiudicialem confessionem in iudicium deductam, iudicis est, perpensis omnibus adiunctis, aestimare quanti ea sit facienda."

39 Can. 1753: "Confessio sive scriptis, sive oretenus, ipsimet adversario aut aliis extra iudicium facta, dicitur extraiudicialis: eaque in iudicium deducta, iudicis est, perpensis omnibus rerum adiunctis, aestimare quanti facienda sit."

$40 \quad$ PM 116: "Confessio extraiudicialis coniugis, quae adversus matrimonii valorem pugnet, prolata ante matrimonium contractum, vel post matrimonium, sed temppore non suspecto, probationis adminiculum constituit a iudice recte aestimandum."

41 Usp. Giordano Caberletti, Le dichiarazioni delle parti (artt. 177-182), u: Il giudizio di nullità matrimoniale dopo l'Istruzione "Dignitas connubii”, Parte terza, La 
S obzirom na terminologiju, pak, praksa Rimske rote pokazuje da izraz confessiones koristi u širem smislu. Ono uključuje i iskaze stranaka kao i njihove izjave, i to ne samo contra se nego napose protiv ženidbenog veza, što se očituje u parnicama isključenja same ženidbe, isključenja njezina bitnog sastavnog dijela ili bitnog svojstva. ${ }^{42}$

Različite presude Rimske rote pokazuju i različite pristupe vrednovanju izjava stranaka i njihova priznanja. Rezultira kako su sudsko i izvansudsko priznanje temeljni pri utvrđivanju duševnog stanja stranke koja je sklopila ženidbu pod uvjetom. ${ }^{43}$

Sljedeći primjer ukazuje kako su izjave stranke koja je hinila ženidbu početak i temelj dokazivanja parnica ništavosti ženidbe sklopljene zbog himbe. ${ }^{44}$ Valja naglasiti kako poteškoća prihvaćanja izjava stranke koja je hinila može biti nadvladana uz pomoć vjerodostojnih svjedoka te drugih pokazatelja i pomagala, kako proizlazi iz presuda. ${ }^{45}$

Nadalje, izjave stranke koja je sklopila ženidbu zbog straha temeljne su pri utvrđivanju njezina unutarnjeg stanja u vrijeme izricanja privole te imaju svoju posebnu težinu. ${ }^{46}$

Zaključno, praksa Rimske rote pokazuje značajne pomake $\mathrm{u}$ vrednovanju izjave stranaka kao dokaznoga materijala, proširujući tako odredbu analiziranih kanona, napose kan. 1536 §2 te kan. 1679.

parte dinamica del processo, Città del Vaticano, 2008., 353-354.

42 Usp. Paolo Bianchi, È più facile, col nuovo Codice di diritto canonico, dimostrare la nullità di un matrimonio? I canoni 1536, § 2 e 1679, Quaderni di diritto ecclesiale, 3 (1990.), 397-398.

43 Usp. c. Palestro, 17. 12. 1986., u: Apostolicum Rotae Romanae Tribunal, Decisiones seu sententiae 1986., str. 731, br. 7; c. Boccafola, 27. 5. 1987., u: Apostolicum Rotae Romanae Tribunal, Decisiones seu sententiae 1987., str. 326-327, br. 12-13; c. Funghini, 24. 2. 1988., u: Apostolicum Rotae Romanae Tribunal, Decisiones seu sententiae 1988., str. 146-147, br. 11.

44 Usp. c. Bruno, 31. 5. 1985., u: Apostolicum Rotae Romanae Tribunal, Decisiones seu sententiae 1985., str. 273, br. 5; c. Doran, 28. 10. 1988., u: Apostolicum Rotae Romanae Tribunal, Decisiones seu sententiae 1988., str. 592, br. 6; c. Burke, 13. 6. 1988., u: Apostolicum Rotae Romanae Tribunal, Decisiones seu sententiae 1988., str. 382, brr. 10-11.

45 Usp. c. Giannecchini, 14. 6. 1988., u: Apostolicum Rotae Romanae Tribunal, Decisiones seu sententiae 1988., str. 396, br. 10; c. Boccafola, 5. 12. 1988., u: Apostolicum Rotae Romanae Tribunal, Decisiones seusententiae 1986., str. 714, br. 6.

46 Usp. c. Bruno, 25. 5. 1984., u: Apostolicum Rotae Romanae Tribunal, Decisiones seu sententiae 1984., str. 321, br. 6; c. Stankiewicz, 26. 6. 1986., u: Apostolicum Rotae Romanae Tribunal, Decisiones seu sententiae 1986., str. 404, br. 12; c. De Lanversin, 23. 11. 1988., u: Apostolicum Rotae Romanae Tribunal, Decisiones seu sententiae 1988., str. 674-675, br. 15-18. 


\section{M.P. MITIS IUDEX DOMINUS IESUS I REVALORIZACIJA IZJAVA STRANAKA}

Nepovjerenje i dvojbeni stav s obzirom na dokaznu snagu izjava i priznanja stranaka samo su djelomično prevladani aktualnim Zakonikom, unatoč činjenici vrednovanja izjava i priznanja stranaka od strane crkvenih sudova. Možda je upravo stanje u praksi potaknulo Kongregaciju za nauk vjere da u poznatom Pismu biskupima Katoličke Crkve o podjeljivanju pričesti ponovno civilno vjenčanima, između ostaloga, u nove načine dokazivanja ništavosti ženidbe navede i dokaznu snaga izjave stranaka te razboritost suca pri njezinu vrednovanju. ${ }^{47}$

Ipak, ključni pomak s obzirom na materiju unijela je reforma procesa proglašenja ništavosti ženidbe proglašena m. p. Mitis Iudex Dominus Iesus, 2015. godine. ${ }^{48}$ Temeljne naglaske reforme mogli bismo sažeti u tri točke. Veća uključenost biskupa u djelovanje crkvenih sudova zasigurno je prva točka reforme. Upravo je biskup, $\mathrm{u}$ prvome redu, temelj sigurnosti ispravne primjene novih norma. Reformom je, nadalje, uvelike pojednostavljen i ubrzan postupak proglašenja ništavosti ženidbe. Ipak, brži postupak ne podrazumijeva lakši put dolasku do proglašenja ništavosti. Treća točka, u najvećoj mjeri vezana uz sadržaj rada, blizina je vjernika (stranaka) i suca u postupku. ${ }^{49}$

Unatoč određenim kritikama, prije svega usmjerenima na postupak processus brevior, s pohvalama je protumačen novi pristup valorizaciji izjava i priznanja stranaka.

Reformirani kan. $1678 \S 1$, za razliku od prethodno analiziranog kan. 1679, puno veći prostor otvara izjavama i priznanju stranaka

47 Congregazione per la discipl ina dei sacramenti, Lettera ai Vescovi della Chiesa Cattolica circa la recezione della comunione eucharistica da parte di fedeli divorziati risposati, AAS 86 (1994.), 978: "La disciplina della Chiesa, mentre conferma la competenza esclusiva dei tribunali ecclesiastici nell'esame della validità del matrimonio dei cattolici, offre anche nuove vie per dimostrare la nullità della precedente unione, allo scopo di escludere per quanto possibile ogni divario tra la verità verificabile nel processo e la verità oggettiva conosciuta dalla retta coscienza." U noti 18, a koja se referira na citirani tekst, spominju se izjave i priznanja stranaka.

48 Motu proprio, Mitis Iudex Dominus Iesus (15. kolovoza 2015.), u: AAS, CVII (2015,) 9, 958- 970.

49 Usp. Ivica Ivanković Radak, Reforma kanonskog postupka proglašenja ništavosti ženidbe. Promjene u redovitom postupku, Obnovljeni život, 71 (2016.) 4, 503504. S druge strane, mišljenje pojedinaca potvrđuje govor o reformi, ali podržava i govor o preustroju kanonskog postupka vezanog uz parnice ništavosti ženidbe. Vidi: Tomislav Đukez, Nova reforma ženidbenog postupka, Vjesnik Đakovačkoosječke nadbiskupije i Srijemske biskupije, CXLVI (2018.) 1, 54-55. 
potvrđenih svjedocima de credibilitate. ${ }^{50}$ Tako je konačno zaživjelo ono što su još nakon proglašenja Zakonika kanonskoga prava iz 1917. zastupali neki od kanonista.

Razlog navedenoj promjeni, prije svega, mogao bi se potražiti u nepraktičnosti procjene dokazne snage izjava stranaka ukoliko im se morao pridodati dodatni dokazni materijal kako bi poslužile u rješavanju dvojbe o (ne)valjanosti ženidbe. Ovakav pristup obvezivao je čak i kada je već na temelju izjave stranaka bila evidentna ništavost ženidbe. Prema kan. 1678 \& 1 izjave i priznanja potkrijepljeni možebitnim svjedocima o vjerodostojnosti samih stranaka, mogu imati snagu potpunog dokaza, a koje sudac vrednuje procijenivši sve pokazatelje i pomagala, osim ako se pridruže drugi elementi koji ih opovrgavaju. Međutim, valja napomenuti kako dokazna snaga u ovome slučaju ne proizlazi ex lege, nego na temelju razborite procjene suca ukoliko nema elemenata koji bi stvarali dvojbu u rečeno. ${ }^{51}$ Povjerenje ukazano strankama u postupku isključuje odviše rigorističko ograničavanje vrijednosti izjava i priznanja. Ipak, nužno je primjenom nove odredbe kan. 1678 \& 1 izbjeći ujedno i svaki dojam laksizma, prema kojemu bi se izjavama stranaka automatski pridodala dokazna snaga i odustalo od traženje možebitnih drugih dokaza. U pri$\log$ tomu govori i činjenica prema kojoj bi se iz kan. 1678 § 1 mogla izdvojiti tri uvjeta prema kojima bi se sudskom priznanju i izjavama stranaka dala snaga potpunog dokaza. Kao prvo, sucu je prepuštena mogućnost potkrijepiti sudsko priznanje i izjave stranaka vjerodostojnim svjedocima. Drugo, potpuna dokazna snaga sudskom priznanju i izjavama stranaka uključuje obvezu suca procijeniti sve pokazatelje i pomagala. Treće, sudsko priznanje i izjave stranaka izričito isključuju elemente koji bi doveli u pitanje istinitost rečenoga. ${ }^{52}$

U ovome slučaju, dakle, radi se o strankama koje su uvjerene u ništavost sklopljene ženidbe, a čiju vjerodostojnost potkrepljuju svjedoci. Ne čudi, stoga, što pojedini kanonisti ovaj novi okvir dokazne snage izjava i priznanja stranaka vide kao rješenje proble-

50 Can. 1678 §1 m.p. Mitis Iudex Dominus Iesus glasi: "In causis de matrimonii nullitate, confessio iudicialis et partium declarationes, testibus forte de ipsarum partium credibilitate sustentae, vim plenae probationis habere possunt, a iudice aestimandam perpensis omnibus indiciis et adminiculis, nisi alia accedant elementa quae eas infirment."

51 Tako Del Pozzo tvrdi kako spomenuta izravna dokazna snaga zahtijeva "un possibile riscontro positivo (la concordanza con gli altri indizi e appigli logici), un necessario riscontro negativo (l'assenza di prove direttamente contrarie) e un'eventuale integrazione (la deposizione di testi sull'affidabilità della parte)". M. Del Pozzo, Il processo matrimonial e puì breve davanti al vescovo, Roma, 2016., 183.

52 Usp. Slavko Zec, Mitis Iudex Dominus Iesus, 99. 
ma takozvane "ništavosti u savjesti". ${ }^{53}$ Upravo bi se na ovaj način mogao prevladati sukob između foro externo e foro interno u pitanjima subjektivno nevaljane ženidbe, objektivno nedokazive te, eventualno, posljedično sklapanja novog (iregularnog) braka sa svim posljedicama koje nosi na sakramentalnome području. Ukoliko se, prema mišljenju onih koji se bave ovom problematikom, svaka ništavost ženidbe mora i objektivno dokazati jer ženidba kao takova nije samo stvar odnosa dvije osobe i Boga već je stvarnost Crkve, ${ }^{54}$ upravo kan. 1678 \& 1 nudi odgovor. Dakako, valja ponoviti, uz oprez i izbjegavajući svaki oblik laksizma.

\section{ZAKLJUČAK}

U parnicama koje se tiču privatnoga dobra sudska izjava stranke čini apsolutni dokaz i oslobađa drugu stranku obveze dokazivanja. U parnicama javnoga dobra, među kojima je i proglašenje ništavosti ženidbe, Zakonik kanonskoga prava nudi normativu kojoj je potrebno pristupiti pojedinačno, od slučaja do slučaja. Kratak povijesni prikaz pristupa materiji, dopušta zaključiti kako je položaj izjave i priznanja stranaka, kao dokaznoga materijala, pratio polagani progres. Zakonik kanonskoga prava iz 1917. čak ih i nije svrstavao $\mathrm{u}$ rang ostalih dokaza, a praksa ih je samo u određenim situacijama i pod određenim uvjetima valorizirala. Aktualnim Zakonikom kanonskoga prava samo je djelomično nadvladana skeptičnost ozbiljnome vrednovanju izjava stranaka. S druge pak strane, upravo su primjeri presuda Rimske rote pokazali da ih uzimaju kao apsolutni i jedini dokaz za proglašenje ništavosti ženidbe ukoliko ne postoje drugi dokazi, ili barem oni koji bi bili suprotni danim izjavama.

Zasigurno je praksa, u ovome slučaju, uvjetovala i normativnu promjenu izraženu kan. 1678 §1 m.p. Mitis Iudex Dominus

53 Usp. Paolo Binchi, Nullità di matrimoni non dimostrabili. Equivoco o problema pastorale, Quaderni di diritto ecclesiale, 3 (1993.) 282; H. Franceschi, Divorziati risposati e nullità matrimoniali, Ius Ecclesiae, 25 (2013.), 617 ss. O tzv. "ništavosti u savjesti" vidi Ivan Pavao II., Familiaris consortio - Obiteljska zajednica. Apostolska pobudnica o zadaćama kršćanske obitelji u suvremenom svijetu (22. XI. 1981.), Zagreb, 1981., br. 84.

54 Gerhard Ludwig Müller, Indissolubilità del matrimonio e dibattito sui divorziati risposati e i sacramenti, L'Osservatore Romano, 23 listopada 2013, 4: "Se i divorziati risposati sono soggettivamente nella convinzione di coscienza che il precedente matrimonio non era valido, ciò deve essere oggettivamente dimostrato dalla competente autorità giudiziaria in materia matrimoniale. Il matrimonio non riguarda solo il rapporto tra due persone e Dio, ma è anche una realtà della Chiesa, un sacramento, sulla cui validità non solamente il singolo per se stesso, ma la Chiesa, in cui egli mediante la fede e il Battesimo è incorporato, è tenuta a decidere." 
Iesus. Novom normativom nije se dogodila samo formalna izmjena već je promijenjen i dosadašnji stav prema strankama u postupku, odnosno njihovu doprinosu dokaznoj fazi postupka. Novi i značajni pomak zakonodavca upravo u strankama vidi one koji konačnoj presudi o (ne)valjanosti ženidbe mogu pridonijeti ne samo subjektivno nego i objektivno, vlastitim izjavama, kako bi i trebalo biti. Neosporno je, nadalje, kako kan 1678 §1 zaista pruža svojevrsnu perspektivu rješavanja slučajeva onih osoba koje su u savjesti uvjerene u ništavost vlastite ženidbe, a koju objektivno ne mogu dokazati. Ipak, za ispunjenje svrhe ove normativne promjene nužna je i velika doza razboritosti. Pretpostaviti je kako svaki sudac koji donosi presude na ovome delikatnome području upravo tu kvalitetu i posjeduje.

\section{PARTIES' DECLARATIONS AND FACTS CONFESSIONS IN THE PROCESS OF DECLARING MARRIAGE NULL AND VOID}

\section{Summary}

In the ordinary contentious trial of the annulment of the marriage, confessions and declarations of the parties are the centre point of determination of validity of marriage. The Canon Law of 1983, in the cc. 1530-1538 describes the canonical norms about the declarations of the parties. The first part of the article analyses an iter of the interrogation of the parties: the purpose of the interrogation; the judge's authority and obligations; the mode of asking questions during the trial; obligations of parties to respond to the questions; refusal of parties to respond to the questions.

The second part considers different types of the interrogation of the parties as judicial and extra-judicial confession, a probative force of their confessions and declarations together and a short retrospection on the practice of Roman Rote and how the Supreme Court of the Catholic Church values the content of the answers during the canonical proceeding of the annulment of the marriage. The final part of the article analyses the changes introduced with m.p. Mitis Iudex Dominus Iesus thanks to which a judicial confession and the declarations of the parties, possibly supported by witnesses to the credibility of the parties, can have the force of full proof to be evaluated by the judge, unless other elements that weaken them are present.

Key words: parties, confessions, declarations, proofs, m.p. Mitis Iudex Dominus Iesus. 